\title{
Playing With Matches: The Czech Constitutional Court's Ultra Vires Revolution
}

verfassungsblog.de/playing-matches-czech-constitutional-courts-ultra-vires-revolution/

Jan Komárek Mi 22 Feb 2012

Mi 22 Feb

2012

\section{By JAN KOMAREK}

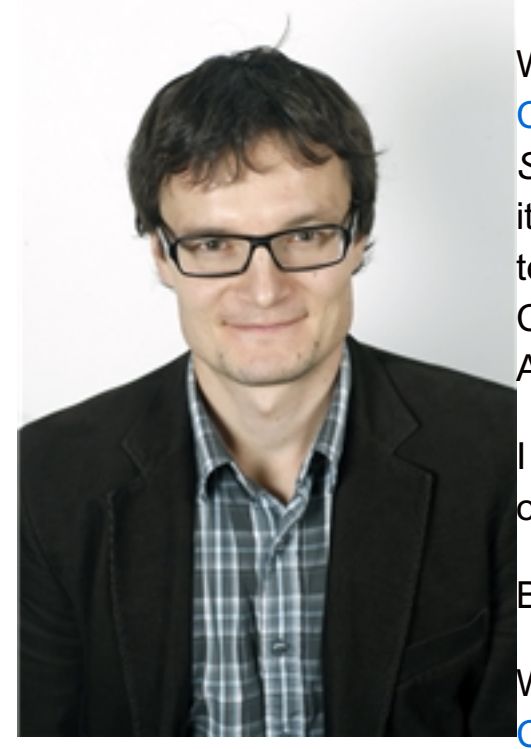

When the Czech Constitutional Court (CCC) declared the CJEU's judgment in C-399/09 Landtová "ultra vires", one of my colleagues commented: "giving Solange into their hands was like to let children play with matches". I am afraid it is the adequate description of the decision, which is difficult to explain in legal terms and which in my view has much more to do with the psychology of the Court and its individual judges, although other domestic actors, the Supreme Administrative Court and the Government, also played an important role. I suspect many readers of this blog will have to check the CJEU's website in order to know what Landtová case was about.

\section{By JAN KOMAREK}

When the Czech Constitutional Court (CCC) declared the CJEU's judgment in C-399/09 Landtová "ultra vires", one of my colleagues commented: "giving Solange into their hands was like to let children play with matches". I am afraid

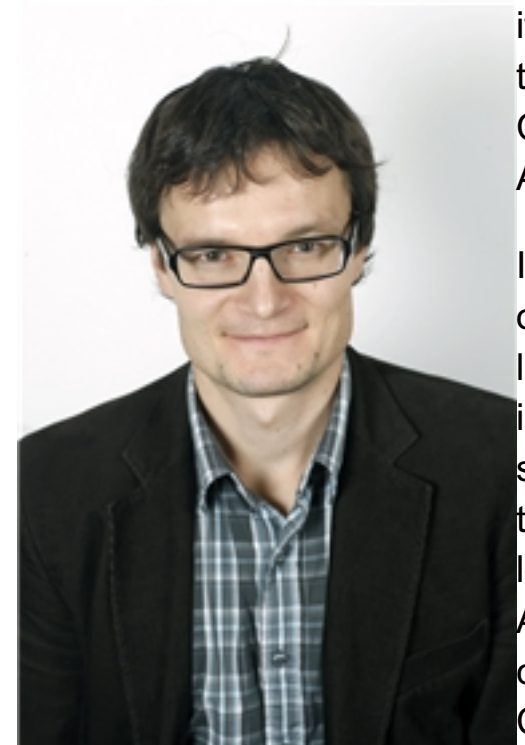
it is the adequate description of the decision, which is difficult to explain in legal terms and which in my view has much more to do with the psychology of the Court and its individual judges, although other domestic actors, the Supreme Administrative Court and the Government, also played an important role.

I suspect many readers of this blog will have to check the CJEU's website in order to know what Landtová case was about. From the point of view of EU law it was an ordinary case, decided by the Fourth Chamber, concerning the interpretation of Regulation No 1408/71 on the application of social security schemes to employed persons, to self-employed persons and to members of their families moving within the Community ("the Regulation"). Only at a closer look one could reveal an interesting dimension to it: the Czech Supreme Administrative Court (the SAC) was challenging the CCC's case law concerning special pension increments that the CCC ordered to be paid to the Czech citizens, who were affected by the dissolution of Czechoslovakia in 1992.

\section{Background to the conflict between the CCC and SAC}

After the dissolution the two succession countries had to establish who was going to be responsible for paying the pensions of Czechoslovak citizens. Article 20 of the Agreement concluded by the Czech and Slovak Republic ("the C-S Agreement") stipulated that the applicable scheme and the authority with competence to grant such benefits would be determined by the State of residence of the employer at the time of dissolution. Some people, who may have not moved from the Czech part of the then Czechoslovak federation during their entire life (except for holidays, perhaps), but whose employer had residence in the Slovak part, therefore obtained their pension (or its proportion) from Slovakia. This led towards the end of 1990s to a series of disputes, since the pensions in Slovakia were significantly lower than those paid in the Czech Republic (now it is the contrary, at least for some categories of people). The $\mathrm{CCC}$ found this to violate the right to adequate material security in old 
age (firstly in the judgment of 3. 6. 2003, II. ÚS 405/02).

The SAC never accepted this case law and initiated a protracted conflict with the CCC: the decision commented here is in fact the $17^{\text {th }}$ in the line, which concerns various aspects of the matter. The SAC argued, among other things, that the special increment was incompatible with EU law.

The first argument was based on the fact that the C-S Agreement became part of the Regulation, which contains in its Annex III provisions of social security conventions that remain applicable notwithstanding the general rule according to which the Regulation replaces such conventions. Article 20 of the C-S Agreement was included in this Annex and in the SAC's view the CCC's interpretation changed the meaning of this provision - now part of the Regulation - and affected the way in which the pension is calculated according to it.

The second argument was based on the discrimination created by the CCC decisions: in general, by virtue of the Regulation (and just mentioned Annex), Article 20 of the C-S Agreement applies not only to Czech and Slovak citizens, but to any EU citizen who is retiring after the Czech Republic's accession to the EU and who had before the dissolution of Czechoslovakia worked there. The CCC's judgments have, however, limited the special increment to the Czech citizens only - excluding all others.

\section{The CJEU's ruling in Landtová Case}

The CCC rejected these arguments in its judgment of 20. 3. 2007, PI. 4/06 - without having asked preliminary reference to the CJEU, although its ruling necessarily involved the interpretation of the Regulation. We should add here, that in another judgment of 12. 8. 2010, III.ÚS 1012/10, the CCC quashed the SAC decision to suspend the proceedings in another Slovak pensions case and to await the CJEU's ruling in the Landtová Case. The CCC ruled that it "has already dealt with the SAC's interpretation and application of European law in the matter, which constituted ratio decidendi of the judgment". In other words, the CCC stated that its interpretation of the Regulation shall prevail in the case regardless of the outcome of the CJEU's ruling, so to await its results violated the rights to a fair trial of the petitioner in question.

On the reference from the SAC, C-399/09 Landtová, the CJEU ruled that while the special increment did not violate the Regulation as such, "the documents before the Court show[ed] incontrovertibly that the [CCC's] judgment discriminate[d], on the ground of nationality, between Czech nationals and the nationals of other Member States" (para. 43). It added that "no evidence capable of justifying such discrimination has been adduced before the Court" (para. 47).

This reflects the fact that the Czech Government submitted observations which openly admitted that the CCC's case law was contrary to EU law - rightly criticized by the CCC as "unprecedented". However, the CJEU wanted to "soften" the consequences of its ruling: the special increment could be maintained, but must be paid to all EU citizens. At the same time, the CJEU observed that "EU law does not, provided that the general principles of EU law are respected, preclude measures to re-establish equal treatment by reducing the advantages of the persons previously favoured" (para. 53). It added, that "before such measures are adopted, there is no provision of EU law which requires that a category of persons who already benefit from supplementary social protection, such as that at issue in the main proceedings, should be deprived of it" (ibid.), stressing once again that the Czech Republic can adopt a solution that would satisfy both the requirements of EU law and the Czech Constitution as interpreted by the CCC.

\section{The reaction to the Landtová ruling}

The reaction of the Czech authorities, however, was not to the CCC's pleasing. First, with a specific reference to the CJEU's ruling the Parliament adopted an act which prospectively excluded the possibility of paying the special increment to everyone.

For the SAC the response of the CJEU was somewhat precarious. While the CJEU confirmed that it was right in considering the special increment unlawful, the former did not exclude that it can be granted to Mrs. Landtová. In 
the concrete case at hand the SAC was therefore supposed (or at least not prevented by EU law) to grant the increment to Mrs. Landtová.

Instead, the SAC came up with a different interpretation: because the CCC created the special increment in violation of EU law - and in particular the violation of its duty to refer preliminary question to the CJEU, its case law cannot be binding on the SAC, the SAC argued. In an ironic twist the SAC took advantage from the CCC'S ruling which found that such a violation would qualify as a breach of the constitutional right to the lawful judge (another irony lies in the fact that this ruling concerned a violation by the SAC...). The SAC challenged the CCC even further, stating that it of course did not undermine the CCC's role as the final arbiter of constitutionality. But the only possibility for the CCC, the SAC stressed, would be to find that the relevant provisions of EU law violated the material core of the Constitution. The SAC therefore provoked the CCC to call revolution, if it wanted to stick to its case law.

When I saw this last SAC's judgment I did not expect the CCC would do so. It did.

\section{The CCC's "ultra vires ruling"}

The fact that a constitutional court of a Member State of the EU declared a judgment of the CJEU "ultra vires" is not something I would automatically condemn. I have always found presumptuous the writings that stressed the post-communist Member States' courts' need to "learn", or which reacted to some of their judgments, which did not correspond to the CJEU's orthodoxy, with suspicions concerning the competence of the respective judges, who were said to have "misunderstood" what it entailed to be the EU. The way in which the CCC justified its move, however, is most insulting - not only to the CJEU, whose accommodating gesture was returned by the $\mathrm{CCC}$ with a slap in the face, but to anybody who cares about the constitutional arrangements in the EU in general, and the Czech Republic's place therein in particular.

The core argument put forward by the CCC was that the CJEU applied the Regulation to the legal relationships regulated by the C-S Agreement. In the CCC's view the Annex to this Regulation lists the provisions of social security conventions which remain applicable differently from the Regulation. The CCC's case law, creating a special pension increment based on Art. 20 of the C-S Agreement was among those provisions and the Regulation itself, in the CCC's view provided for such differentiated treatment of Czech nationals.

Unfortunately (for the CCC), the Regulation emphasises that "save as provided in Annex III, the provisions of social security conventions which remain in force ... shall apply to all persons to whom this Regulation applies". Annex III then contains two lists of social security conventions and only those contained in part B of the Annex can provide for a differentiated treatment of certain categories of people". Article 20 of the C-S Agreement is not amongst them; it cannot, therefore, establish differentiated treatment for certain categories of people.

Moreover, the Regulation of course cannot violate the provisions of the Treaties, including the prohibition on discrimination on the basis of nationality. Thus Regulation No. 647/2005, which amended the Annex, stresses in the fourth recital of its Preamble:

On the basis of the case-law relating to the relationships between Regulation (EEC) No 1408/71 and the provisions of bilateral social security agreements, it is necessary to review Annex III to that Regulation. ... In addition, it is not appropriate to accept entries in part $B$ except where exceptional and objective situations justify a derogation from Article 3(1) of that Regulation and from Articles 12, 39 and 42 of the Treaty.

This only confirms that the discrimination found by the CJEU could hardly be justified in case the relevant provision was not expressly mentioned in part B of Annex III (although the CJEU hinted at such a possibility, as mentioned above).

However, the CCC found the very application of the Regulation inappropriate. In its view, "the provisions of Annex III are from the point of view of EU law of declaratory nature only, they are not constitutive; the key consideration for the application of the Regulation is the nature of the legal relationships concerned, which must contain the so called foreign element". This foreign element was lacking, according to the CCC, since "the 
periods of employment during the existence of Czechoslovakia cannot be viewed, retroactively, as periods of employment abroad".

The key passage of the judgment, trying to explain why the CCC considered the CJEU's ruling ultra vires is the following:

"Not to distinguish legal arrangements following from the dissolution of a state with a single social security system from the arrangements concerning the consequences for social security systems of the free movement of persons in the European Communities, or the European Union, amounts to the failure to respect the European history, it means to compare the incomparable. For this reason it is not possible to apply European law, ie. the Regulation, to the Czech citizens' claims stemming from social security. Following the principle explicitly stated in its judgment [of 26. 11. 2008, Pl. ÚS 19/08, Lisbon Treaty I], it is not possible to do otherwise than to find in relation to the consequences of the [CJEU's judgment in the Landtová Case] for similar cases that in its [the CJEU'S] case the situation where an act of an institution of the EU exceeded the competences transferred to the EU by virtue of Article 10a of the Czech Constitution occurred, that an act ultra vires was occurred".

First, the CCC's assertion that "the provisions of Annex III are from the point of view of EU law of declaratory nature only" is plainly wrong. In fact the CCC implies that the content of those provisions is to be determined autonomously from EU law - so that they can e.g. be "amended" by a ruling of a national constitutional court, such as the decisions of the $\mathrm{CCC}$ ordering the payment of a special increment to Czech citizens negatively affected by the application of Article 20 of the C-S agreement. The truth is that those provisions became part of the Regulation - providing for a special regime within the Regulation and their interpretation thus became a matter of EU law - where the final word lies with the CJEU, not the CCC. This relates to the second argument, already mentioned: that the CCC's decisions, creating the special increment, established unequal treatment. As such, they would have to be listed in another part of Annex III - but they were not.

Such a misunderstanding could be perhaps understandable, if it did not lead to the finding of ultra vires ruling on the part of the CJEU. While the CCC ornamentally refers to the BVerfG's rulings concerning the possibilities of its intervention, everybody who has ever had a look at these decisions would know that they are quite different - if only because the BVerfG suggested that it would firstly send a preliminary reference to the CJEU before finding its ruling ultra vires. As one of my colleagues commented on this, well-behaving people firstly try to talk to each other before pressing the trigger. Not the CCC.

Well, the CCC wanted to invent its own way of talking to the CJEU; instead of submitting a preliminary reference the Court sent a letter to the CJEU, where it wanted to explain its case law, as it saw that it was not be properly defended by the Government. The Registry, however, sent the letter back to the CCC, explaining that "according to what is established practice, the members of the CJEU do not exchange correspondence with third parties concerning the cases submitted to the CJEU".

This apparently insulted the judges in Brno. The CCC "pointed to the deficits concerning the guarantees of the fair trial in the procedure in [the Landtová Case]". In relation to its rejected letter the CCC "reminded that the CJEU regularly uses the institute of amici curiae in preliminary ruling procedure, in particular in relation to the Commission. in the situation when the ECJ was aware, that the Czech Republic as a party to the proceedings, acting through its government, which rejected the CCC's opinion, which was the object of the CJEU's assessment, it is impossible to see the CJEU's finding that the CCC's was a 'third party' in the case otherwise than a violation of the principle of audiatur et altera pars".

Leaving aside a truly groundbreaking finding - also constitutional courts enjoy the guarantees of a fair trial! - the CCC demonstrated that it knew rather little about the relevant rules concerning preliminary ruling procedure, whereby the Commission (and the Member State Governments together with other institutions and also the parties to the case before the referring court) are invited to submit observations (Art. 23 of the CJEU's Statute), no such provision is made for national courts and other institutions. Thus the CJEU's rejection was fully in line with the rules which govern the procedure before it.

But there is another mystery: why did the CCC want to decapitate itself into the position of a party before the CJEU and complained about the latter's rejection of its letter, if it had numerous possibilities of sending the 
reference to the CJEU, including in this case?

\section{Consequences}

In the Czech Republic only few people seem to have comprehended what the CCC did, except for the circles close to both courts involved and the Government. The CCC's judgment contained other problematic elements which I did not have space to deal with (such as declaring the statute adopted by the legislature in response to the Landtová ruling "obsolete", since the CCC did not have the competence to annul it in this case) and these will have to be discussed by the relevant actors.

One possibility I proposed on the Czech blog mentioned above was to await the change in the CCC's composition, which is due in the course of this and the following year and try to postpone decisions in cases that deal with the same problem until this change. Some people suggest that the SAC should either simply ignore the CCC or to send another reference to the CJEU asking it on the effect of the CCC's finding that the former's ruling was ultra vires (what could the CJEU say?) It remains to be seen what (if anything) the reaction of the EU will be.

Jan Komarek is a lecturer in EU law at the London School of Economics and Political Science. From the point of view of EU law it was an ordinary case, decided by the Fourth Chamber, concerning the interpretation of Regulation No 1408/71 on the application of social security schemes to employed persons, to self-employed persons and to members of their families moving within the Community ("the Regulation"). Only at a closer look one could reveal an interesting dimension to it: the Czech Supreme Administrative Court (the SAC) was challenging the CCC's case law concerning special pension increments that the CCC ordered to be paid to the Czech citizens, who were affected by the dissolution of Czechoslovakia in 1992.

\section{Background to the conflict between the CCC and SAC}

After the dissolution the two succession countries had to establish who was going to be responsible for paying the pensions of Czechoslovak citizens. Article 20 of the Agreement concluded by the Czech and Slovak Republic ("the C-S Agreement") stipulated that the applicable scheme and the authority with competence to grant such benefits would be determined by the State of residence of the employer at the time of dissolution. Some people, who may have not moved from the Czech part of the then Czechoslovak federation during their entire life (except for holidays, perhaps), but whose employer had residence in the Slovak part, therefore obtained their pension (or its proportion) from Slovakia. This led towards the end of 1990s to a series of disputes, since the pensions in Slovakia were significantly lower than those paid in the Czech Republic (now it is the contrary, at least for some categories of people). The CCC found this to violate the right to adequate material security in old age (firstly in the judgment of 3. 6. 2003, II. ÚS 405/02).

The SAC never accepted this case law and initiated a protracted conflict with the CCC: the decision commented here is in fact the $17^{\text {th }}$ in the line, which concerns various aspects of the matter. The SAC argued, among other things, that the special increment was incompatible with EU law.

The first argument was based on the fact that the C-S Agreement became part of the Regulation, which contains in its Annex III provisions of social security conventions that remain applicable notwithstanding the general rule according to which the Regulation replaces such conventions. Article 20 of the C-S Agreement was included in this Annex and in the SAC's view the CCC's interpretation changed the meaning of this provision - now part of the Regulation - and affected the way in which the pension is calculated according to it.

The second argument was based on the discrimination created by the CCC decisions: in general, by virtue of the Regulation (and just mentioned Annex), Article 20 of the C-S Agreement applies not only to Czech and Slovak citizens, but to any EU citizen who is retiring after the Czech Republic's accession to the EU and who had before the dissolution of Czechoslovakia worked there. The CCC's judgments have, however, limited the special increment to the Czech citizens only - excluding all others.

\section{The CJEU's ruling in Landtová Case}


The CCC rejected these arguments in its judgment of 20. 3. 2007, PI. 4/06 - without having asked preliminary reference to the CJEU, although its ruling necessarily involved the interpretation of the Regulation. We should add here, that in another judgment of 12. 8. 2010, III.ÚS 1012/10, the CCC quashed the SAC decision to suspend the proceedings in another Slovak pensions case and to await the CJEU's ruling in the Landtová Case. The CCC ruled that it "has already dealt with the SAC's interpretation and application of European law in the matter, which constituted ratio decidendi of the judgment". In other words, the CCC stated that its interpretation of the Regulation shall prevail in the case regardless of the outcome of the CJEU's ruling, so to await its results violated the rights to a fair trial of the petitioner in question.

On the reference from the SAC, C-399/09 Landtová, the CJEU ruled that while the special increment did not violate the Regulation as such, "the documents before the Court show[ed] incontrovertibly that the [CCC's] judgment discriminate[d], on the ground of nationality, between Czech nationals and the nationals of other Member States" (para. 43). It added that "no evidence capable of justifying such discrimination has been adduced before the Court" (para. 47).

This reflects the fact that the Czech Government submitted observations which openly admitted that the CCC's case law was contrary to EU law - rightly criticized by the CCC as "unprecedented". However, the CJEU wanted to "soften" the consequences of its ruling: the special increment could be maintained, but must be paid to all EU citizens. At the same time, the CJEU observed that "EU law does not, provided that the general principles of EU law are respected, preclude measures to re-establish equal treatment by reducing the advantages of the persons previously favoured" (para. 53). It added, that "before such measures are adopted, there is no provision of EU law which requires that a category of persons who already benefit from supplementary social protection, such as that at issue in the main proceedings, should be deprived of it" (ibid.), stressing once again that the Czech Republic can adopt a solution that would satisfy both the requirements of EU law and the Czech Constitution as interpreted by the CCC.

\section{The reaction to the Landtová ruling}

The reaction of the Czech authorities, however, was not to the CCC's pleasing. First, with a specific reference to the CJEU's ruling the Parliament adopted an act which prospectively excluded the possibility of paying the special increment to everyone.

For the SAC the response of the CJEU was somewhat precarious. While the CJEU confirmed that it was right in considering the special increment unlawful, the former did not exclude that it can be granted to Mrs. Landtová. In the concrete case at hand the SAC was therefore supposed (or at least not prevented by EU law) to grant the increment to Mrs. Landtová.

Instead, the SAC came up with a different interpretation: because the CCC created the special increment in violation of EU law - and in particular the violation of its duty to refer preliminary question to the CJEU, its case law cannot be binding on the SAC, the SAC argued. In an ironic twist the SAC took advantage from the CCC's ruling which found that such a violation would qualify as a breach of the constitutional right to the lawful judge (another irony lies in the fact that this ruling concerned a violation by the SAC...). The SAC challenged the CCC even further, stating that it of course did not undermine the CCC's role as the final arbiter of constitutionality. But the only possibility for the CCC, the SAC stressed, would be to find that the relevant provisions of EU law violated the material core of the Constitution. The SAC therefore provoked the CCC to call revolution, if it wanted to stick to its case law.

When I saw this last SAC's judgment I did not expect the CCC would do so. It did.

\section{The CCC's "ultra vires ruling"}

The fact that a constitutional court of a Member State of the EU declared a judgment of the CJEU "ultra vires" is not something I would automatically condemn. I have always found presumptuous the writings that stressed the post-communist Member States' courts' need to "learn", or which reacted to some of their judgments, which did 
not correspond to the CJEU's orthodoxy, with suspicions concerning the competence of the respective judges, who were said to have "misunderstood" what it entailed to be the EU. The way in which the CCC justified its move, however, is most insulting - not only to the CJEU, whose accommodating gesture was returned by the CCC with a slap in the face, but to anybody who cares about the constitutional arrangements in the EU in general, and the Czech Republic's place therein in particular.

The core argument put forward by the CCC was that the CJEU applied the Regulation to the legal relationships regulated by the C-S Agreement. In the CCC's view the Annex to this Regulation lists the provisions of social security conventions which remain applicable differently from the Regulation. The CCC's case law, creating a special pension increment based on Art. 20 of the C-S Agreement was among those provisions and the Regulation itself, in the CCC's view provided for such differentiated treatment of Czech nationals.

Unfortunately (for the CCC), the Regulation emphasises that "save as provided in Annex III, the provisions of social security conventions which remain in force ... shall apply to all persons to whom this Regulation applies". Annex III then contains two lists of social security conventions and only those contained in part B of the Annex can provide for a differentiated treatment of certain categories of people". Article 20 of the C-S Agreement is not amongst them; it cannot, therefore, establish differentiated treatment for certain categories of people.

Moreover, the Regulation of course cannot violate the provisions of the Treaties, including the prohibition on discrimination on the basis of nationality. Thus Regulation No. 647/2005, which amended the Annex, stresses in the fourth recital of its Preamble:

On the basis of the case-law relating to the relationships between Regulation (EEC) No 1408/71 and the provisions of bilateral social security agreements, it is necessary to review Annex III to that Regulation. ... In addition, it is not appropriate to accept entries in part B except where exceptional and objective situations justify a derogation from Article 3(1) of that Regulation and from Articles 12, 39 and 42 of the Treaty.

This only confirms that the discrimination found by the CJEU could hardly be justified in case the relevant provision was not expressly mentioned in part B of Annex III (although the CJEU hinted at such a possibility, as mentioned above).

However, the CCC found the very application of the Regulation inappropriate. In its view, "the provisions of Annex III are from the point of view of EU law of declaratory nature only, they are not constitutive; the key consideration for the application of the Regulation is the nature of the legal relationships concerned, which must contain the so called foreign element". This foreign element was lacking, according to the CCC, since "the periods of employment during the existence of Czechoslovakia cannot be viewed, retroactively, as periods of employment abroad".

The key passage of the judgment, trying to explain why the CCC considered the CJEU's ruling ultra vires is the following:

"Not to distinguish legal arrangements following from the dissolution of a state with a single social security system from the arrangements concerning the consequences for social security systems of the free movement of persons in the European Communities, or the European Union, amounts to the failure to respect the European history, it means to compare the incomparable. For this reason it is not possible to apply European law, ie. the Regulation, to the Czech citizens' claims stemming from social security. Following the principle explicitly stated in its judgment [of 26. 11. 2008, PI. ÚS 19/08, Lisbon Treaty I], it is not possible to do otherwise than to find in relation to the consequences of the [CJEU's judgment in the Landtová Case] for similar cases that in its [the CJEU's] case the situation where an act of an institution of the EU exceeded the competences transferred to the EU by virtue of Article 10a of the Czech Constitution occurred, that an act ultra vires was occurred".

First, the CCC's assertion that "the provisions of Annex III are from the point of view of EU law of declaratory nature only" is plainly wrong. In fact the CCC implies that the content of those provisions is to be determined autonomously from EU law - so that they can e.g. be "amended" by a ruling of a national constitutional court, such as the decisions of the CCC ordering the payment of a special increment to Czech citizens negatively affected by the application of Article 20 of the C-S agreement. The truth is that those provisions became part of 
the Regulation - providing for a special regime within the Regulation and their interpretation thus became a matter of EU law - where the final word lies with the CJEU, not the CCC. This relates to the second argument, already mentioned: that the CCC's decisions, creating the special increment, established unequal treatment. As such, they would have to be listed in another part of Annex III - but they were not.

Such a misunderstanding could be perhaps understandable, if it did not lead to the finding of ultra vires ruling on the part of the CJEU. While the CCC ornamentally refers to the BVerfG's rulings concerning the possibilities of its intervention, everybody who has ever had a look at these decisions would know that they are quite different - if only because the BVerfG suggested that it would firstly send a preliminary reference to the CJEU before finding its ruling ultra vires. As one of my colleagues commented on this, well-behaving people firstly try to talk to each other before pressing the trigger. Not the CCC.

Well, the CCC wanted to invent its own way of talking to the CJEU; instead of submitting a preliminary reference the Court sent a letter to the CJEU, where it wanted to explain its case law, as it saw that it was not be properly defended by the Government. The Registry, however, sent the letter back to the CCC, explaining that "according to what is established practice, the members of the CJEU do not exchange correspondence with third parties concerning the cases submitted to the CJEU".

This apparently insulted the judges in Brno. The CCC "pointed to the deficits concerning the guarantees of the fair trial in the procedure in [the Landtová Case]". In relation to its rejected letter the CCC "reminded that the CJEU regularly uses the institute of amici curiae in preliminary ruling procedure, in particular in relation to the Commission. in the situation when the ECJ was aware, that the Czech Republic as a party to the proceedings, acting through its government, which rejected the CCC's opinion, which was the object of the CJEU's assessment, it is impossible to see the CJEU's finding that the CCC's was a 'third party' in the case otherwise than a violation of the principle of audiatur et altera pars".

Leaving aside a truly groundbreaking finding - also constitutional courts enjoy the guarantees of a fair trial! - the CCC demonstrated that it knew rather little about the relevant rules concerning preliminary ruling procedure, whereby the Commission (and the Member State Governments together with other institutions and also the parties to the case before the referring court) are invited to submit observations (Art. 23 of the CJEU's Statute), no such provision is made for national courts and other institutions. Thus the CJEU's rejection was fully in line with the rules which govern the procedure before it.

But there is another mystery: why did the CCC want to decapitate itself into the position of a party before the CJEU and complained about the latter's rejection of its letter, if it had numerous possibilities of sending the reference to the CJEU, including in this case?

\section{Consequences}

In the Czech Republic only few people seem to have comprehended what the CCC did, except for the circles close to both courts involved and the Government. The CCC's judgment contained other problematic elements which I did not have space to deal with (such as declaring the statute adopted by the legislature in response to the Landtová ruling "obsolete", since the CCC did not have the competence to annul it in this case) and these will have to be discussed by the relevant actors.

One possibility I proposed on the Czech blog mentioned above was to await the change in the CCC's composition, which is due in the course of this and the following year and try to postpone decisions in cases that deal with the same problem until this change. Some people suggest that the SAC should either simply ignore the CCC or to send another reference to the CJEU asking it on the effect of the CCC's finding that the former's ruling was ultra vires (what could the CJEU say?) It remains to be seen what (if anything) the reaction of the EU will be.

Jan Komarek is a lecturer in EU law at the London School of Economics and Political Science. 
Revolution, VerfBlog, 2012/2/22, http://verfassungsblog.de/playing-matches-czech-constitutional-courts-ultravires-revolution/. 